\title{
Fatty acid composition of blubber of the Baikal seal Phoca sibirica and its marine relative, the ringed seal $P$. hispida
}

\author{
Otto Grahl-Nielsen ${ }^{1, *}$, Ann-Kristin Halvorsen ${ }^{1}$, Nikolai Bodoev ${ }^{2,3}$, Lena Averina ${ }^{2}$, \\ Larisa Radnaeva ${ }^{2,3}$, Nikolai Pronin ${ }^{4}$, Reijo Käkelä ${ }^{5}$, Eygenii Petrov ${ }^{6}$ \\ ${ }^{1}$ Department of Chemistry, University of Bergen, 5007 Bergen, Norway \\ ${ }^{2}$ Baikal Institute of Natural Management SB RAS, 630033 Ulan-Ude, Russia \\ ${ }^{3}$ Buryat State University, 630000 Ulan-Ude, Russia \\ ${ }^{4}$ Institute of General and Experimental Biology SB RAS, 630033 Ulan-Ude, Russia \\ ${ }^{5}$ Department of Biology, University of Joensuu, 80101, Finland \\ ${ }^{6}$ East Siberian Fish Centre, 630000 Ulan-Ude, Russia
}

\begin{abstract}
The fatty acid (FA) composition was determined in the blubber of 5 adult Baikal seals Phoca sibirica caught in July 2001, nine 1-mo old pups caught in April 2002, and 25 adults and fetuses from 3 of these, caught in October 2002, all along the SE shores of Lake Baikal, eastern Siberia. For comparison, FA in the blubber of ringed seals $P$. hispida, the closest marine relative of the Baikal seal, caught along the ice edge around Svalbard during 1999 and 2000 were also analyzed. The FA of the main prey of the Baikal and ringed seals, the endemic golomyanka Comephorus baikalensis and polar cod Boreogadus saida, respectively, were also studied. The same suite of FA was found in all samples. Saturated FA (SFA) with branched chains, all n6 polyunsaturated FA (PUFA) and 18:3n3 and 20:3n3 were more abundant in the blubber of the Lake Baikal seal and in the golomyanka than in the blubber of the marine ringed seal and marine fishes. In contrast, the relative levels of monounsaturated FAs (MUFA) with 20 and 22 carbons and polyunsaturated 20:5n3 were lower in the Baikal species than in the Svalbard species. The FA composition of the inner blubber was significantly different from the FA composition of the outer blubber in both species. Despite large differences in FA composition between Baikal and ringed seal blubbers, vertical differences were manifested in the same FA: MUFA with 14, 16 and 18 carbons were present in higher relative abundance in the outer than in the inner layer. In both species all the other quantitatively important FA had lower or equal relative values in the outer layer. The FA composition of the seals' blubber differed from that of their main prey. The difference was, however, smaller between prey and inner blubber than between prey and outer blubber. The FA composition of the inner blubber of adults showed temporal differences. Since the change from prey to blubber in relative concentration occurred in the same direction for all but 5 FA, the selection of FA during deposition in the inner blubber was similar for the 2 species, even though there was a large difference between the general FA composition of the freshwater and marine lipids. The FA composition in the blubber of adults, pups and fetuses differed.
\end{abstract}

KEY WORDS: Baikal seal · Ringed seal · Blubber stratification · Fatty acid composition · Prey · Endogenous factors

Resale or republication not permitted without written consent of the publishe

\section{INTRODUCTION}

Lake Baikal, eastern Siberia, is the world's oldest (25 million yr), deepest $(1637 \mathrm{~m})$ and largest (23000 $\mathrm{km}^{3}$ ) freshwater reservoir. The Baikalian fauna diverged in the Tertiary period, and $>80 \%$ of the 800 species inhabiting the open waters of the lake are endemic. The top predator, and the only endemic mammal of the lake, is the Baikal seal Phoca sibirica. A recent study of its mitochondrial DNA suggests that its ancestor reached Lake Baikal approximately 0.4 million yr ago, apparently through the Yenisei-Angara 
waterway (Sasaki et al. 2003), and that it is much more closely related to the ringed seal $P$. hispida than to the Caspian seal $P$. caspica. In 2000 the population was calculated at 75800 seals of $\geq 1 \mathrm{yr}$ of age (Petrov 2000). The seals have adapted to the unique conditions of the deep and cold Lake Baikal, with its extended periods of ice cover, stable food reserves and the specific spatial and vertical distribution of the seals' main prey (Stewart et al. 1997). Adaptations at the ecological and physiological level have resulted in morphological changes to the Baikal seal, which can be distinguished from the ringed and Caspian seals by karyotype, structure of the skull and skeleton, and dimorphism of the sexes (Pastukhov 1993).

Lipids play an important role in essential metabolic processes of aquatic organisms and provide a major energy store for growth and reproduction. The large amount of lipids in the blubber of marine mammals (up to $50 \%$ of the body weight of some species at certain life stages; Iverson 2002) has been the subject of many investigations. These investigations have concentrated on the FA, the 'building-blocks' of the lipids, and have attempted to provide insight into ecological (Walton \& Pomeroy 2003, Iverson et al. 2004), taxonomical (Fredheim et al. 1995, Smith et al. 1996, Durnford \& Shahidi 2002) and medicinal (Bang \& Dyerberg 1976, Shahidi et al. 1996) aspects.

The FA composition of the blubber of Baikal seals has not yet been systematically investigated. The only attempt dates back to early 1980, when some of the blubber FA were identified (Demchenko et al. 1982). However, the FA composition of the blubber of the Arctic ringed seal, Phoca hispida hispida, and 3 other subspecies isolated after the last glacial maximum, i.e. P. hispida botnica from the Baltic Sea, P. hispida ladogensis from Lake Ladoga, Russia, and P. hispida saimensis from Lake Saimaa, Finland, has been determined (Käkelä et al. 1993, Käkelä \& Hyvärinen 1996, 1998). Lake Ladoga and Lake Saimaa are shallow lakes with dark humic water and large annual fluctuations in water temperature, i.e. with conditions very different from those in Lake Baikal. Because of its very low salinity, the species composition at every trophic level of the food web in Lake Baikal differs from that in the Arctic Ocean. For example crustaceans, which store energy as wax esters, are abundant in the oceans but absent from Lake Baikal (Morris 1983). All these ecological differences affect the basic biochemistry of the food web and the FA available for transfer to upper trophic levels (Morris 1984).

Since the Baikal seal and the ringed seal are evolutionarily and genetically related, but live at the top of biologically and biochemically very different food webs, it was of interest to determine which features in the FA composition of their blubber differ and are affected by dietary FA, and which are similar, i.e. endogenous and independent of dietary FA. In our study, we focused on: (1) differences in FA composition between the inner and outer blubber and how this chemical stratification is affected by dietary FA, (2) how the dietary FA composition of the prey is modified prior to or at the deposition phase in the inner blubber of the seals, (3) differences in FA composition among the Baikal seal adults, pups and fetuses, and (4) differences in the FA composition of adult Baikal seals captured at different times. In view of the ongoing dispute on the usefulness of blubber FA to identify prey species quantitatively (see Grahl-Nielsen et al. 2004, Thiemann et al. 2004), it is crucial to differentiate the effects of diet and endogeneous metabolic factors of individuals of different age on the composition of FA in their blubber.

\section{MATERIALS AND METHODS}

Field methods. During harvesting (with the approval of the Buryat Fish and Game authorities), 5 Baikal seals aged 2 to 6 yr were netted at Ushkanyi Island, Lake Baikal, on 20 July 2001, and 9 pups aged 20 to $30 \mathrm{~d}$ were caught on the ice of Lake Baikal near Enheluk on April 4 2002. In addition 28 adults were netted on 23 to 26 October 2002 in Chivyrkuiskiy Bay (Fig. 1, Table 1). A few hours after the seals had been killed, approximately $10 \times 10 \mathrm{~cm}$ sections were cut

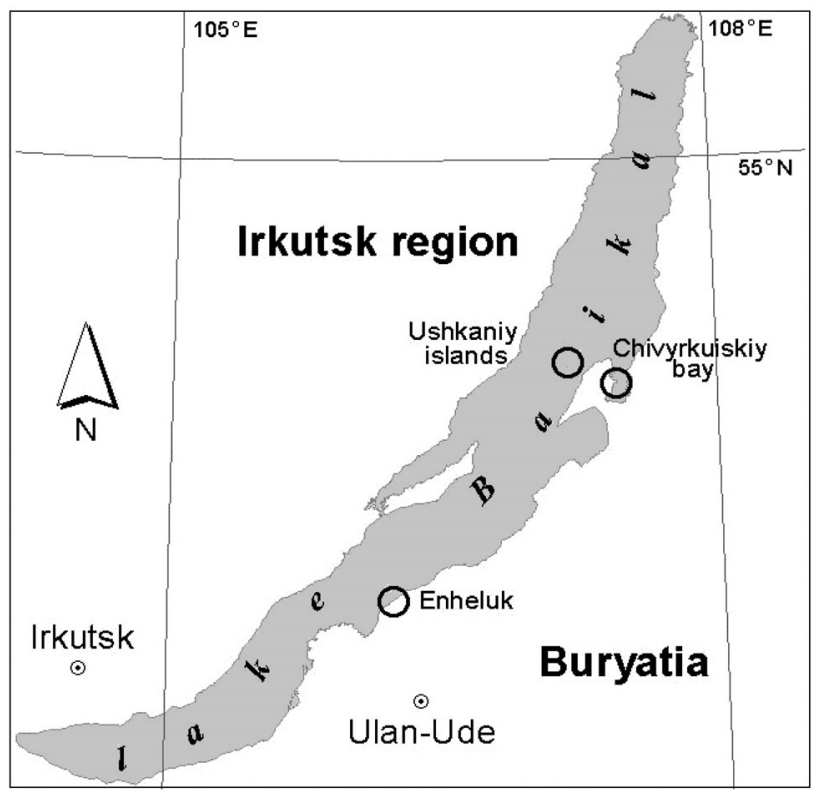

Fig. 1. Lake Baikal. Baikal seals Phoca sibirica were sampled at Ushkaniy Islands in July 2001, at Enheluk in April 2002 and in Chivyrkuiskiy Bay in October 2002 
through the whole layer of the blubber from the skin to the muscle, mid-dorsally at approximately $2 / 5$ of the distance from snout to tail. The thickness of the blubber varied between 4 and $7 \mathrm{~cm}$, but was not correlated with seal age. Subsamples weighing approximately 20 mg were cut from the pieces of blubber close to the

Table 1. Phoca sibirica. Baikal seals sampled in Lake Baikal for blubber analysis. Seals 1 to 5 were sampled at Ushkanyi Island, the 9 pups near Enheluk, and the remaing 26 adults in Chivyrkuiskiy Bay (Fig. 1). F: female; M: male; nd: no data

\begin{tabular}{|c|c|c|c|c|c|}
\hline $\begin{array}{l}\text { Sampling date } \\
\text { Seal No. }\end{array}$ & Age & Sex & $\begin{array}{c}\text { Weight } \\
(\mathrm{kg})\end{array}$ & $\begin{array}{l}\text { Length } \\
(\mathrm{cm})\end{array}$ & $\begin{array}{l}\text { Blubber } \\
\text { (cm) }\end{array}$ \\
\hline \multicolumn{6}{|l|}{20 July 2001} \\
\hline 1 & $3 \mathrm{yr}$ & $\mathrm{F}$ & 22.5 & 90 & 4.5 \\
\hline 2 & 2 & $\mathrm{M}$ & 25 & 99 & 5 \\
\hline 3 & 2 & $\mathrm{~F}$ & 19.7 & 98 & 3.5 \\
\hline 4 & 2 & $\mathrm{~F}$ & 34 & 114 & 6 \\
\hline 5 & 8 & $\mathrm{M}$ & nd & 158 & 3.5 \\
\hline \multicolumn{6}{|l|}{04 April 2002} \\
\hline Pup 1 & $30 \mathrm{~d}$ & M & 12.5 & 90 & 3 \\
\hline Pup 2 & 30 & $\mathrm{~F}$ & 10 & 71 & 2.5 \\
\hline Pup 3 & 30 & $\mathrm{~F}$ & 13 & 74 & 2.7 \\
\hline Pup 4 & 30 & $\mathrm{M}$ & 11 & 75 & 3.0 \\
\hline Pup 5 & 25 & $\mathrm{~F}$ & 12 & 74 & 1.8 \\
\hline Pup 6 & 21 & $\mathrm{~F}$ & 9 & 53 & 1.5 \\
\hline Pup 7 & 30 & $\mathrm{~F}$ & 10 & 75 & 2.5 \\
\hline Pup 8 & 25 & $\mathrm{~F}$ & 7.5 & 75 & 1.8 \\
\hline Pup 9 & 30 & $\mathrm{M}$ & 14 & 79 & 2.3 \\
\hline \multicolumn{6}{|c|}{23 October 2002} \\
\hline 25 & $13 \mathrm{yr}$ & $\mathrm{F}$ (pregnant) & 74 & 130 & 6.5 \\
\hline \multicolumn{6}{|c|}{24 October 2002} \\
\hline 24 & 9 & $\mathrm{~F}$ & 80 & 131 & 7 \\
\hline 94 & 8 & $\mathrm{M}$ & nd & 152 & 7 \\
\hline 38 & 3 & $\mathrm{M}$ & nd & 125 & nd \\
\hline 39 & 10 & $\mathrm{~F}$ & nd & 148 & 6 \\
\hline 96 & 10 & $\mathrm{~F}$ (pregnant) & nd & 140 & 9 \\
\hline 90 & 5 & $\mathrm{~F}$ & nd & 113 & 6 \\
\hline 35 & 22 & $\mathrm{~F}$ & 73 & 122 & 7 \\
\hline 34 & 13 & $\mathrm{~F}$ (pregnant) & 93 & 132 & 9 \\
\hline 27 & 5 & $\mathrm{M}$ & 29 & 123 & 5 \\
\hline 37 & 29 & $\mathrm{~F}$ & 56 & 146 & 7 \\
\hline 91 & 2 & $\mathrm{~F}$ & nd & 112 & 4 \\
\hline 29 & 22 & $\mathrm{~F}$ (pregnant) & 98 & 140 & 6 \\
\hline 93 & 7 & $\mathrm{~F}$ & 53 & 115 & 7 \\
\hline \multicolumn{6}{|c|}{26 October 2002} \\
\hline 74 & 8 & $\mathrm{M}$ & 34 & 106 & 3 \\
\hline 80 & 4 & M & 49 & 113 & 6 \\
\hline 72 & 11 & $\mathrm{~F}$ & 85 & 128 & 6 \\
\hline 97 & 2 & $\mathrm{~F}$ & 94 & 135 & 5 \\
\hline 84 & 7 & $\mathrm{~F}$ (pregnant) & 65 & 123 & 7.5 \\
\hline 99 & 23 & $\mathrm{~F}$ (pregnant) & nd & 146 & nd \\
\hline 85 & 10 & $\mathrm{~F}$ (pregnant) & nd & 147 & 8 \\
\hline 21 & 8 & $M$ & 34 & 106 & 3 \\
\hline 87 & 25 & $\mathrm{~F}$ (pregnant) & 89 & 143 & 8 \\
\hline 76 & 28 & $\mathrm{~F}$ & 87 & 130 & 6 \\
\hline 86 & 5 & $\mathrm{~F}$ (pregnant) & nd & 126 & 6 \\
\hline 98 & 8 & $\mathrm{~F}$ (pregnant) & 78 & 130 & 6 \\
\hline 70 & 7 & $\mathrm{M}$ & 61 & 116 & 5 \\
\hline 75 & 7 & $\mathrm{~F}$ & 89 & 137 & 8 \\
\hline
\end{tabular}

skin and close to the muscle, carefully avoiding crosscontamination of liquid fat along the blubber column. Likewise, subsamples of the approximately $1 \mathrm{~cm}$ thick adipose tissue of 3 fetuses were collected. The samples were transferred to thick-walled, $15 \mathrm{ml}$ glas tubes with Teflon-lined screw caps.

Ringed seals $(\mathrm{N}=12)$ were harvested by permission of the Governor of Svalbard (Sysselmannen) along the ice edge in the Greenland Sea (west of Svalbard), Barents Sea (east of Svalbard) and the Arctic Ocean (north of Svalbard) during 1999 and 2000, and subsamples of blubber were retrieved as described above.

Golomyanka and polar cod were netted at Ushkanyi Island, Lake Baikal, on 20 July 2001 and on the west coast of Svalbard in July 2000, respectively. We thoroughly homogenized 3 specimens from each species individually, and subsamples of approximately $40 \mathrm{mg}$ were transferred to glass tubes, 1 subsample from each of the 3 polar cod and 2 parallel subsamples from each of the 3 golomyankas.

Laboratory methods. The samples were methanolyzed/extracted in a 1-step procedure (Grahl-Nielsen \& Barnung 1985) by treatment with $0.5 \mathrm{ml}$ anhydrous methanol containing $\mathrm{HCl}$ at a concentration of $2 \mathrm{~mol} \mathrm{l}^{-1}$ for $2 \mathrm{~h}$ in an oven at $90^{\circ} \mathrm{C}$. After cooling to room temperature, half the methanol was evaporated by nitrogen gas, and $0.5 \mathrm{ml}$ distilled water was added. The resulting FA methyl esters (FAME) were extracted from the methanol/water phase with $2 \times 1.0 \mathrm{ml}$ hexane. The concentration of the FAME in the combined extracts was adjusted by addition of hexane to levels suitable for gas chromatography.

We injected $1 \mu$ l of the mixed hexane extracts splitless, and chromatographed this on a $25 \mathrm{~m} \times 0.25 \mathrm{~mm}$ fused-silica column, with polyethyleneglycol as stationary phase (thickness of $0.2 \mu \mathrm{m}$; CP-WAX 52CB Chrompack) and helium at 20 psi as mobile phase. The column was mounted in a Hewlett-Packard 5890A gas chromatograph equipped with a Hewlett-Packard 7673A autosampler and a flame-ionization detector. The injector temperature was $260^{\circ} \mathrm{C}$. The temperature of the column was kept at $90^{\circ} \mathrm{C}$ for 4 min after injection and thereafter increased to $165^{\circ} \mathrm{C}$ at rate of $30^{\circ} \mathrm{C} \mathrm{min}{ }^{-1}$, followed by an increase of $3^{\circ} \mathrm{C} \min ^{-1}$ to $225^{\circ} \mathrm{C}$. This temperature was maintained for $10.5 \mathrm{~min}$. The flameionization detector was set at $330^{\circ} \mathrm{C}$. Samples were analyzed in random order with a standard solution (GLC-68D from Nu-Chek-Prep; Elysian, Minnesota, USA) containing 20 FAME, between every 8th sample. Altogether, 50 quantitatively most important FA were identified in the samples, using the standard mixture and previous experience of relative retention times of FAME and mass spectrometry. The peaks were integrated by Atlas 1.1 software and the areas were corrected by response factors. These empirical response 
factors, relative to 18:0, were calculated for the 20 FAME present in known amounts in the standard mixture. An average of 10 runs of the standard mixture was used for these calculations. For each of the 30 FAMEs for which we had no standards, we estimated the response factors using that standard FAME which resembled it most closely in terms of chain length and number of double bonds. The amount of each FA in a sample was expressed as percent of the sum of all FA in the sample.

The stratification index was calculated for the blubber FA by subtracting the percentage of the FA in the inner layer from the percentage in the outer layer and dividing the difference by the mean of the percentages in the 2 layers.

Statistical methods. To obtain the combined information from all 50 FA simultaneously, the data were subjected to multivariate treatment based on principal component analysis (PCA). The relative values of the FA were logarithmically transformed, thereby levelling out the quantitative differences among the FA. With each sample positioned in the multidimensional space described by the log-transformed variables (FA), the 2 coordinates (principal components, PCs) that described the largest and second largest variance among the samples were computed with the program package SIRIUS (Kvalheim \& Karstang 1987). In this manner the main systematic variation among the samples was described in 2 dimensions. The samples were displayed in the coordinate system of PC1 versus PC2.

PCA is a qualitative display method. To quantify the observed difference between Baikal seals from July 2001 and October 2002, space-filling models of the 2 groups of samples were built by the program SIMCA ('soft independent modeling of class analogies') (Wold et al. 1984), available in the SIRIUS software package. The distances of the samples to these models were then computed as residual standard deviations (RSD).

\section{RESULTS}

\section{FA in freshwater versus marine seals and their prey}

The same assemblage of $50 \mathrm{FA}$ is present (although in different relative amounts) in the blubber of the Baikal seal and its main prey, golomyanka, as in the blubber of the Arctic ringed seal and its prey, the polar cod (Table 2). There is a systematic difference in the FA composition between the Baikal and the marine species (Table 2, Fig. 2). In saturated FA (SFA), the Baikal seal blubber and golomyanka contain higher relative amounts of branched-chain FA with 15, 17 and
18 carbons than the marine species. In monounsaturated FA (MUFA), the marine species contain 1 order of magnitude higher relative levels of all the doublebond positional isomers of 20:1 and 22:1 than the freshwater species. In polyunsaturated FA (PUFA), all n6 PUFA as well as 18:3n3 and 20:3n3 are clearly more abundant in the blubber of the Baikal seal and in the golomyanka than in the blubber of the marine seal and in marine fishes. In contrast, the marine species contains higher percentages of 20:5n3. In addition, there are differences in the fish FA that are not present, or are much smaller, in the seals; i.e. higher relative levels of SFA in the golomyanka than in the marine fishes and higher relative abundancies of 14:1n5, 18:1n9 and 18:1n7 in the golomyanka (Table 2).

Multivariate PCA demonstrated the clear-cut separation between the Baikal seal and fish (golomyanka), on one hand, and the marine ringed seal and fish (polar cod) on the other (Fig. 3). This separation is the main difference in Fig. 3, and accounts for $53 \%$ of the total variance among the samples.

To determine whether the Baikal seal-ringed seal difference represents a general difference in FA composition between the freshwater and marine seals, the blubber FA composition of harp seals Phoca groenlandica and bearded seals Erignathus barbatus, collected along the ice edge in the Greenland Sea (west of Svalbard), Barents Sea (east of Svalbard) and the Arctic Ocean (north of Svalbard) during 1999 and 2000, was subjected to PCA together with the present data. The data for harp and bearded seals originate from a previous study (Grahl-Nielsen et al. 2003), and since the computations in that study were based on the 22 most prominent FA in the samples, the same FA were selected from the present data for this comparison. The combined information from 22 FA was extracted but, because of the large difference between the inner and outer blubber layer observed in all 4 seal species, the comparison was carried out on the 2 layers independently. There are pronounced differences between the Baikal seal, on one hand, and all 3 marine species on the other (Fig. 4). In regard to within-species variation, the Baikal-marine variance is larger in the outer than in the inner layer of blubber. The variances among the 3 marine species are also more clear-cut in the outer than in the inner blubber.

\section{FA stratification in seal blubber}

The PC plot demonstrating the separation between the seal and fish FA composition in Lake Baikal and Artic Ocean also revealed a difference between the inner and outer blubber layer of the seals (Fig. 3). However, the inner-outer distinction appears not to be 
Table 2. Phoca sibirica (Baikal seal), P. hispida (ringed seal), Comephorus baikalensis (golomyanka) and Boreogadus saida (polar cod). Relative mean amounts (\% of total \pm SD) of fatty acids (FA) in Baikal seal fetuses, pups and adults, in golomyanka, in adult ringed seals and in polar cod. OB: outer blubber; IB: inner blubber; unid: unidentified

\begin{tabular}{|c|c|c|c|c|c|c|c|c|c|}
\hline \multirow[t]{2}{*}{ FA } & \multirow{2}{*}{$\begin{array}{c}\text { Baikal seal } \\
\text { fetuses } \\
(\mathrm{N}=3)\end{array}$} & \multicolumn{2}{|c|}{$\begin{array}{l}\text { Baikal seal pups } \\
\qquad(\mathrm{N}=9)\end{array}$} & \multicolumn{2}{|c|}{$\begin{array}{l}\text { Baikal seal adults } \\
\qquad(\mathrm{N}=30)\end{array}$} & \multirow[t]{2}{*}{$\begin{array}{l}\text { Golomyanka } \\
\qquad(\mathrm{N}=3)\end{array}$} & \multicolumn{2}{|c|}{$\begin{array}{c}\text { Ringed seals } \\
(\mathrm{N}=10)\end{array}$} & \multirow[t]{2}{*}{$\begin{array}{l}\text { Polar cod } \\
(\mathrm{N}=3)\end{array}$} \\
\hline & & $\mathrm{OB}$ & IB & $\mathrm{OB}$ & IB & & $\mathrm{OB}$ & IB & \\
\hline $14: 0$ & $5.0 \pm 0.1$ & $4.0 \pm 0.4$ & $4.2 \pm 0.4$ & $3.8 \pm 0.7$ & $5.9 \pm 0.9$ & $6 \pm 1$ & $3.0 \pm 0.4$ & $4.6 \pm 0.7$ & $3.15 \pm 0.01$ \\
\hline $14: 1 \mathrm{n} 5$ & $1.3 \pm 0.3$ & $1.5 \pm 0.2$ & $0.8 \pm 0.2$ & $2.0 \pm 0.4$ & $0.9 \pm 0.3$ & $0.25 \pm 0.09$ & $1.4 \pm 0.3$ & $0.5 \pm 0.3$ & $0.06 \pm 0.01$ \\
\hline 15:0 & $0.32 \pm 0.01$ & $0.34 \pm 0.02$ & $0.37 \pm 0.03$ & $0.31 \pm 0.04$ & $0.45 \pm 0.08$ & $0.46 \pm 0.04$ & $0.25 \pm 0.04$ & $0.30 \pm 0.03$ & $0.27 \pm 0.01$ \\
\hline $\mathrm{i}-15: 0$ & $0.09 \pm 0.01$ & $0.68 \pm 0.06$ & $0.62 \pm 0.04$ & $0.59 \pm 0.07$ & $0.71 \pm 0.09$ & $0.7 \pm 0.2$ & $0.19 \pm 0.04$ & $0.24 \pm 0.04$ & $0.16 \pm 0.01$ \\
\hline ai-15:0 & $0.11 \pm 0.01$ & $0.28 \pm 0.02$ & $0.27 \pm 0.02$ & $0.29 \pm 0.04$ & $0.31 \pm 0.05$ & $0.31 \pm 0.07$ & $0.08 \pm 0.02$ & $0.08 \pm 0.02$ & $0.03 \pm 0.01$ \\
\hline 16:0 & $24 \pm 3$ & $6.4 \pm 0.4$ & $10 \pm 1$ & $5 \pm 1$ & $11 \pm 2$ & $15.6 \pm 0.3$ & $5 \pm 1$ & $11 \pm 3$ & $9.5 \pm 0.1$ \\
\hline 16:1n9 & $4.0 \pm 0.5$ & $0.75 \pm 0.07$ & $0.69 \pm 0.06$ & $0.7 \pm 0.1$ & $0.7 \pm 0.2$ & $0.41 \pm 0.07$ & $0.6 \pm 0.2$ & $0.3 \pm 0.1$ & \\
\hline $16: 1 \mathrm{n} 7$ & $19 \pm 4$ & $21.5 \pm 0.7$ & $17 \pm 2$ & $20 \pm 2$ & $15 \pm 2$ & $11 \pm 3$ & $20 \pm 3$ & $16.2 \pm 2$ & $11.4 \pm 0.1$ \\
\hline $16: 1 \mathrm{n} 5$ & $0.23 \pm 0.02$ & $0.36 \pm 0.03$ & $0.35 \pm 0.04$ & $0.35 \pm 0.03$ & $0.35 \pm 0.05$ & $0.32 \pm 0.02$ & $0.34 \pm 0.05$ & $0.33 \pm 0.04$ & $0.29 \pm 0.01$ \\
\hline $16: 2 \mathrm{n} 6$ & $0.10 \pm 0.09$ & $0.7 \pm 0.1$ & $0.7 \pm 0.1$ & $0.9 \pm 0.1$ & $1.1 \pm 0.4$ & $1.0 \pm 0.3$ & $0.6 \pm 0.1$ & $0.7 \pm 0.1$ & $0.70 \pm 0.01$ \\
\hline $16: 3 n 4<$ & $<0.01 \pm 0.00$ & $0.26 \pm 0.07$ & $0.24 \pm 0.06$ & $0.3 \pm 0.1$ & $0.4 \pm 0.1$ & $0.5 \pm 0.2$ & $0.15 \pm 0.07$ & $0.30 \pm 0.08$ & $0.38 \pm 0.01$ \\
\hline $16: 4 n 1$ & $0.07 \pm 0.06$ & $0.14 \pm 0.04$ & $0.12 \pm 0.03$ & $0.20 \pm 0.06$ & $0.3 \pm 0.1$ & $0.2 \pm 0.1$ & $0.29 \pm 0.08$ & $0.5 \pm 0.1$ & $0.45 \pm 0.01$ \\
\hline $17: 0$ & $0.5 \pm 0.2$ & $0.32 \pm 0.06$ & $0.43 \pm 0.07$ & $0.24 \pm 0.05$ & $0.40 \pm 0.09$ & $0.29 \pm 0.07$ & $0.09 \pm 0.05$ & $0.10 \pm 0.05$ & $0.14 \pm 0.01$ \\
\hline $\mathrm{i}-17: 0$ & $0.32 \pm 0.08$ & $0.51 \pm 0.02$ & $0.52 \pm 0.03$ & $0.46 \pm 0.08$ & $0.48 \pm 0.07$ & $0.54 \pm 0.02$ & $0.25 \pm 0.08$ & $0.19 \pm 0.04$ & $0.25 \pm 0$ \\
\hline ai-17:0 & $0.25 \pm 0.03$ & $0.5 \pm 0.1$ & $0.55 \pm 0.05$ & $0.55 \pm 0.06$ & $0.6 \pm 0.1$ & $0.69 \pm 0.08$ & $0.11 \pm 0.06$ & $0.09 \pm 0.04$ & $0.07 \pm 0.01$ \\
\hline b-17:1 & $0.1 \pm 0.1$ & $0.22 \pm 0.05$ & $0.21 \pm 0.04$ & $0.25 \pm 0.03$ & $0.27 \pm 0.04$ & $0.27 \pm 0.04$ & $0.09 \pm 0.04$ & $0.07 \pm 0.03$ & $0.18 \pm 0.01$ \\
\hline 17:1n8 & $0.3 \pm 0.1$ & $0.76 \pm 0.04$ & $0.69 \pm 0.05$ & $0.8 \pm 0.1$ & $0.56 \pm 0.08$ & $0.45 \pm 0.08$ & $0.36 \pm 0.07$ & $0.18 \pm 0.06$ & $0.15 \pm 0.01$ \\
\hline 18:0 & $3.2 \pm 0.8$ & $0.59 \pm 0.07$ & $1.3 \pm 0.3$ & $0.6 \pm 0.1$ & $1.5 \pm 0.3$ & $3.0 \pm 0.3$ & $0.5 \pm 0.2$ & $1.3 \pm 0.6$ & $1.76 \pm 0.01$ \\
\hline i-18:0 & $0.02 \pm 0.02$ & $0.24 \pm 0.02$ & $0.26 \pm 0.01$ & $0.26 \pm 0.06$ & $0.24 \pm 0.08$ & $0.5 \pm 0.1$ & $0.09 \pm 0.05$ & $0.08 \pm 0.04$ & \\
\hline 18:1n9 & $21 \pm 1$ & $30 \pm 5$ & $32 \pm 5$ & $24 \pm 6$ & $18 \pm 6$ & & $23 \pm 3$ & $15 \pm 4$ & \\
\hline $18: 1 \mathrm{n} 7$ & $6.5 \pm 0.2$ & $7.1 \pm 0.8$ & $7.6 \pm 0.7$ & $5.9 \pm 0.9$ & $5 \pm 1$ & $4.9 \pm 0.8$ & $5 \pm 1$ & $5 \pm 1$ & \\
\hline 18:1n5 & $0.7 \pm 0.2$ & $0.33 \pm 0.03$ & $0.31 \pm 0.02$ & $0.32 \pm 0.09$ & $0.30 \pm 0.07$ & $0.34 \pm 0.05$ & $0.6 \pm 0.1$ & $0.5 \pm 0.1$ & 02 \\
\hline $18: 2 \mathrm{n} 7$ & $1.2 \pm 0.1$ & $0.25 \pm 0.05$ & $0.20 \pm 0.04$ & $0.22 \pm 0.09$ & $0.15 \pm 0.08$ & $0.05 \pm 0.03$ & $0.12 \pm 0.03$ & $0.08 \pm 0.01$ & $0.04 \pm 0$ \\
\hline $18: 2 \mathrm{n} 6$ & $0.6 \pm 0.1$ & $3.5 \pm 0.4$ & $3.9 \pm 0.4$ & $4.2 \pm 0.7$ & $4.1 \pm 0.5$ & $4.4 \pm 0.8$ & $1.3 \pm 0.1$ & $1.1 \pm 0.2$ & $0.78 \pm 0.02$ \\
\hline $18: 2 \mathrm{n} 4$ & $0.3 \pm 0.1$ & $0.31 \pm 0.03$ & $0.31 \pm 0.03$ & $0.33 \pm 0.03$ & $0.33 \pm 0.04$ & $0.27 \pm 0.05$ & $0.17 \pm 0.04$ & $0.16 \pm 0.03$ & $0.18 \pm 0.02$ \\
\hline 18:3n6 & $0.15 \pm 0.03$ & $0.59 \pm 0.05$ & $0.47 \pm 0.06$ & $0.40 \pm 0.07$ & $0.28 \pm 0.07$ & $0.19 \pm 0.04$ & $0.15 \pm 0.02$ & $0.19 \pm 0.06$ & $0.13 \pm 0.01$ \\
\hline 18:3n3 & $0.13 \pm 0.06$ & $1.6 \pm 0.3$ & $1.7 \pm 0.3$ & $2.3 \pm 0.6$ & $3.0 \pm 0.7$ & $3.0 \pm 0.6$ & $0.6 \pm 0.1$ & $0.7 \pm 0.4$ & $0.48 \pm 0.03$ \\
\hline $18: 4 n 3$ & $0.1 \pm 0.1$ & $2.1 \pm 0.5$ & $1.9 \pm 0.4$ & $2.1 \pm 0.5$ & $2.7 \pm 0.8$ & $2.1 \pm 0.3$ & $1.3 \pm 0.2$ & $2.2 \pm 0.6$ & $2.72 \pm 0.02$ \\
\hline 19:0 & $0.18 \pm 0.09$ & $0.2 \pm 0.1$ & $0.16 \pm 0.06$ & $0.23 \pm 0.07$ & $0.2 \pm 0.1$ & $0.14 \pm 0.02$ & $0.16 \pm 0.06$ & $0.1 \pm 0.1$ & $0.14 \pm 0.01$ \\
\hline $20: 0$ & $0.13 \pm 0.02$ & $0.3 \pm 0.3$ & $0.1 \pm 0.1$ & $0.05 \pm 0.07$ & $0.1 \pm 0.1$ & $0.16 \pm 0.03$ & $0.03 \pm 0.05$ & $0.05 \pm 0.02$ & $0.05 \pm 0.01$ \\
\hline 20:1n11 & $1.8 \pm 0.9$ & $0.1 \pm 0.1$ & $1 \pm 0.1$ & $0.3 \pm 0.1$ & $0.3 \pm 0.2$ & $0.12 \pm 0$. & $1.2 \pm 0.7$ & $1.0 \pm 0.7$ & \\
\hline $20: 1 \mathrm{n} 9$ & $0.35 \pm 0.04$ & & & $0.35 \pm 0$. & & & & & \\
\hline $20: 1 \mathrm{n} 7$ & $0.36 \pm 0.08$ & $0.4 \pm 0.2$ & $0.2 \pm 0$ & $0.3 \pm 0.1$ & $0.3 \pm 0.2$ & $0.20 \pm 0.0$ & $0.3 \pm 0.3$ & $0.4 \pm$ & \\
\hline $20: 2 n 6$ & $1.2 \pm 0.1$ & $0.2 \pm 0.1$ & $0.2 \pm 0.1$ & $0.4 \pm 0.1$ & $0.6 \pm 0.3$ & $0.71 \pm 0.08$ & $0.20 \pm 0.08$ & $0.20 \pm 0.04$ & $0.34 \pm 0.04$ \\
\hline $20: 3 n 3<$ & $<0.01 \pm 0.00$ & $0.17 \pm 0.03$ & $0.18 \pm 0.04$ & $0.20 \pm 0.04$ & $0.23 \pm 0.04$ & $0.28 \pm 0.02$ & $0.06 \pm 0.01$ & $0.08 \pm 0.02$ & $0.05 \pm 0.01$ \\
\hline $20: 4 n 6$ & $2.1 \pm 0.2$ & $1.7 \pm 0.3$ & $1.3 \pm 0.3$ & $2.0 \pm 0.3$ & $2.0 \pm 0.3$ & $4 \pm 2$ & $0.5 \pm 0.2$ & $0.33 \pm 0.09$ & $0.38 \pm 0.02$ \\
\hline $20: 4 n 3$ & $0.03 \pm 0.03$ & $0.4 \pm 0.1$ & $0.3 \pm 0.1$ & $0.6 \pm 0.2$ & $0.6 \pm 0.2$ & $0.38 \pm 0.04$ & $0.53 \pm 0.08$ & $0.6 \pm 0.2$ & $0.64 \pm 0.01$ \\
\hline $20: 5 n 3$ & $1.0 \pm 0.2$ & $3.0 \pm 0.8$ & $2.4 \pm 0.6$ & $4 \pm 1$ & $4 \pm 1$ & $7 \pm 2$ & $8 \pm 1$ & $9 \pm 2$ & $11.0 \pm 0.3$ \\
\hline $21: 5 n 3<$ & $<0.01 \pm 0.00$ & $0.18 \pm 0.06$ & $0.17 \pm 0.05$ & $0.25 \pm 0.07$ & $0.28 \pm 0.09$ & $0.20 \pm 0.04$ & $0.44 \pm 0.08$ & $0.44 \pm 0.08$ & $0.42 \pm 0.01$ \\
\hline $22: 0<$ & $<0.01 \pm 0.00$ & $0.01 \pm 0.01$ & $0.00 \pm 0.01$ & $0.01 \pm 0.02$ & $0.02 \pm 0.02$ & $0.08 \pm 0.01$ & $0.02 \pm 0.01$ & $0.02 \pm 0.01$ & $0.05 \pm 0.01$ \\
\hline $22: 1 n 11$ & $0.04 \pm 0.02$ & $0.03 \pm 0.02$ & $0.04 \pm 0.01$ & $0.01 \pm 0.00$ & $0.01 \pm 0.00$ & $<0.01 \pm 0.00$ & $0.6 \pm 0.4$ & $3 \pm 2$ & $10.5 \pm 0.4$ \\
\hline $22: 1 \mathrm{n} 9<$ & $<0.01 \pm 0.00$ & $0.01 \pm 0.01$ & $0.00 \pm 0.01$ & $0.05 \pm 0.03$ & $0.07 \pm 0.02$ & $0.16 \pm 0.04$ & $0.19 \pm 0.07$ & $0.5 \pm 0.3$ & $1.83 \pm 0.07$ \\
\hline $22: 1 \mathrm{n} 7$ & $0.22 \pm 0.09$ & $0.10 \pm 0.03$ & $0.09 \pm 0.03$ & $0.05 \pm 0.02$ & $0.05 \pm 0.02$ & $0.08 \pm 0.01$ & $0.08 \pm 0.01$ & $0.17 \pm 0.08$ & $0.44 \pm 0.01$ \\
\hline $22: 4 \mathrm{n} 6$ & $0.2 \pm 0.2$ & $0.23 \pm 0.05$ & $0.23 \pm 0.05$ & $0.3 \pm 0.1$ & & $0.16 \pm 0.05$ & $0.05 \pm 0.02$ & & \\
\hline $22: 5 n 6$ & $0.4 \pm 0.1$ & $0.5 \pm 0.1$ & $0.5 \pm 0.2$ & $1.0 \pm 0.4$ & $1.3 \pm 0.5$ & $1.2 \pm 0.4$ & $0.07 \pm 0.03$ & $0.07 \pm 0.03$ & $0.15 \pm 0.09$ \\
\hline $22: 5 n 3$ & $0.5 \pm 0.2$ & $2.2 \pm 0.6$ & $2.2 \pm 0.6$ & $3.4 \pm 0.9$ & $4 \pm 1$ & $0.9 \pm 0.2$ & $4.7 \pm 0.5$ & $4 \pm 1$ & $1.04 \pm 0.04$ \\
\hline $22: 6 \mathrm{n} 3$ & $1.8 \pm 0.5$ & $4 \pm 1$ & $4 \pm 1$ & $7 \pm 2$ & $10 \pm 3$ & $10 \pm 4$ & $10 \pm 1$ & $9 \pm 2$ & $10.4 \pm 0.4$ \\
\hline $24: 0$ & $0.02 \pm 0.02$ & $<0.01 \pm 0.00$ & $<0.01 \pm 0.00$ & $0.01 \pm 0.01$ & $0.01 \pm 0.01$ & $0.05 \pm 0.02$ & $<0.01 \pm 0.0$ & $0.01 \pm 0.01$ & $0.02 \pm 0.01$ \\
\hline 24:1n9 & $0.24 \pm 0.04$ & $0.01 \pm 0.01$ & $0.02 \pm 0.02$ & $0.05 \pm 0.05$ & $0.15 \pm 0.06$ & $1.1 \pm 0.6$ & $0.04 \pm 0.02$ & $0.10 \pm 0.09$ & $0.42 \pm 0.02$ \\
\hline unid & 0.2 & $0.10 \quad 0.03$ & $0.09 \quad 0.03$ & 0.03 & 0.07 & $<0.00$ & 0.01 & 0.01 & 0.2 \\
\hline
\end{tabular}



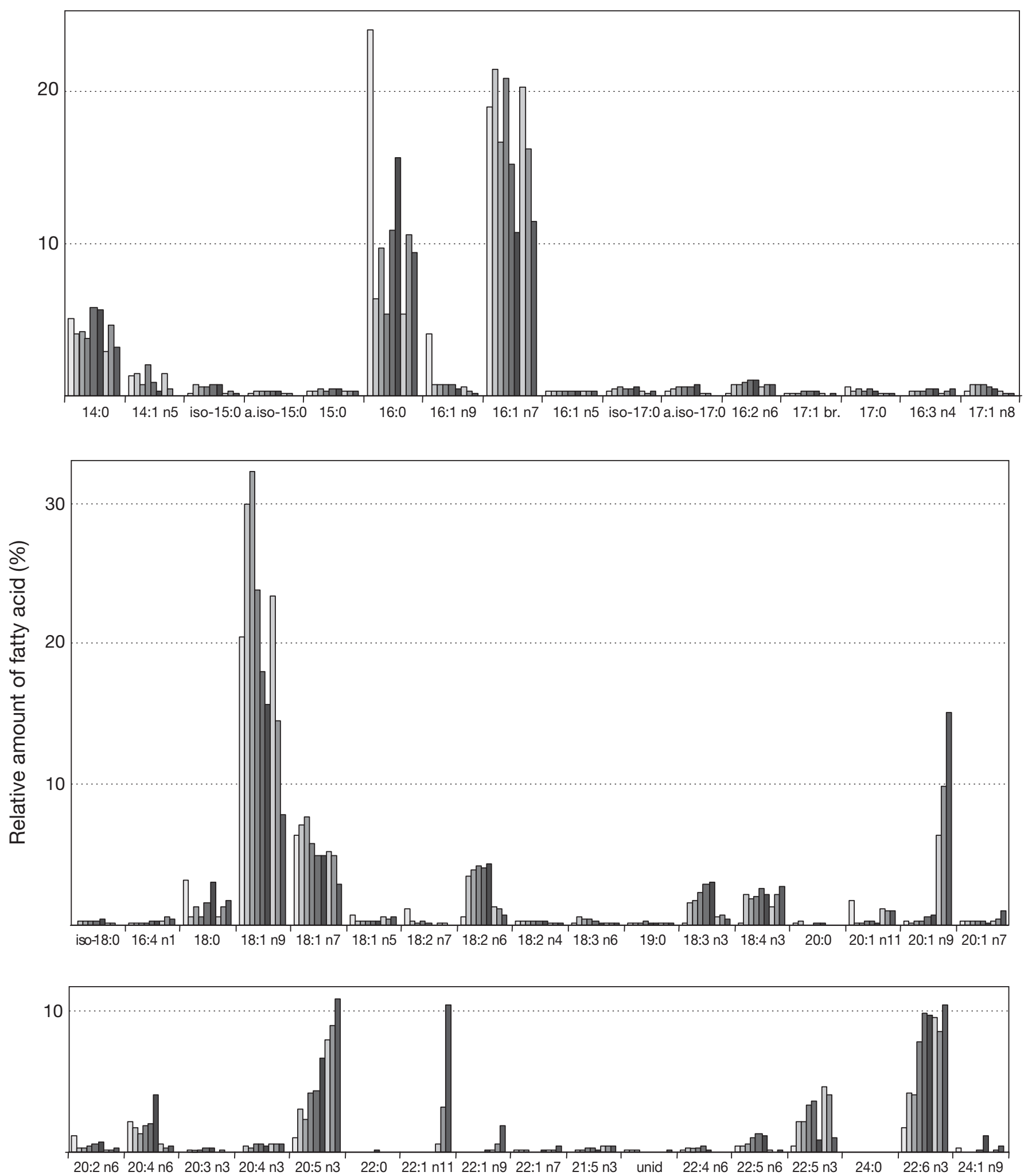

Fig. 2. Phoca sibirica (Baikal seal), P. hispida (ringed seal) Comephorus baikalensis (golomyanka) and Boreogadus saida (polar cod). Relative amounts (percent of total) of 50 fatty acids in blubber of Baikal seal and ringed seal and in the main prey of the seals. The 9 bars for each fatty acid (FA) represent from left to right: Baikal seal fetuses $(\mathrm{N}=3)$, outer and inner blubber layer of Baikal seal pups $(\mathrm{N}=9)$, outer and inner blubber layer of adult Baikal seal $(\mathrm{N}=26)$, golomyanka $(\mathrm{N}=3)$, outer and inner blubber layer of ringed seal $(\mathrm{N}=10)$, and polar $\operatorname{cod}(\mathrm{N}=3)$ 


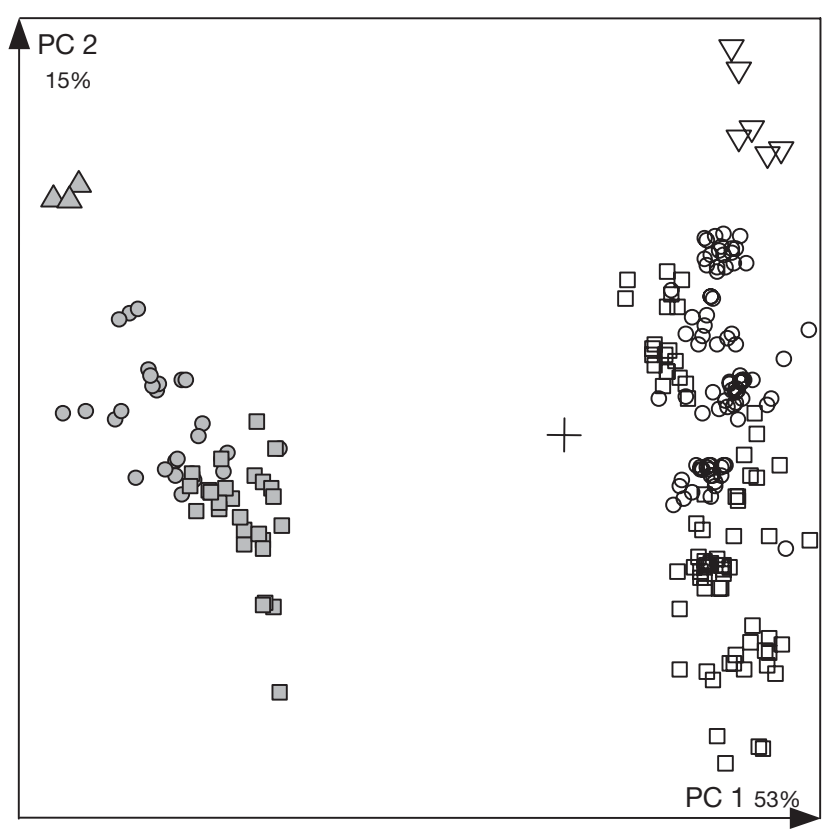

Fig. 3. Phoca sibirica, P. hispida, Comephorus baikalensis and Boreogadus saida. PC plot of samples from blubber of adult seals and prey, based on all 50 FA. Samples from ringed seals $(\mathrm{N}=12)$ and polar cod $(\mathrm{N}=3)$ are on left, samples from Baikal seals $(N=30)$ and golomyanka $(N=3)$ on right. $(O, \square)$ Inner and outer blubber of ringed seal, respectively; $(O, \square)$ inner and outer blubber Baikal seal, respectively; $(\Delta)$ polar $\operatorname{cod}_{i}(\nabla)$ golomyanka. Several replicate samples used for each seal

complete in Fig. 3, where all samples have an influence on their mutual positions. When separate, spacefilling PC models were used for the samples from the inner and outer layers, inter-model tests showed total separation between the inner and outer layers (Fig. 5): some samples fell outside their own model, but no samples fell inside the opposite model.

The inner-outer difference is manifested in the same FA for both species (Fig. 6). The C14 to 18 MUFA are enriched in the outer blubber and the $\mathrm{C} 20$ to $\mathrm{C} 24$ MUFA in the inner blubber; 16:1n9 and 20:1n11 (which, according to their double-bond positions, result from peroxisomal chain-shortening), tend to be more abundant in the outer blubber. The SFA are more abundant in the lipids of the inner blubber, with the exceptions of iso- and anteiso-17:0, and 19:0 in the ringed seal. Among the PUFA, different isomers of 18:2 tend to favor incorporation into the lipids of the outer blubber, and C16 PUFA are deposited preferentially in the inner blubber. In the ringed seal, $20: 4 \mathrm{n} 6$ is more abundant in the outer blubber. Only 3 FA $(18: 3 n 6,22: 5 n 3$ and 22:6n3) have an opposite stratification, and this is of small magnitude.

Given the large and systematic difference between the inner and outer blubber layer, the inner blubber
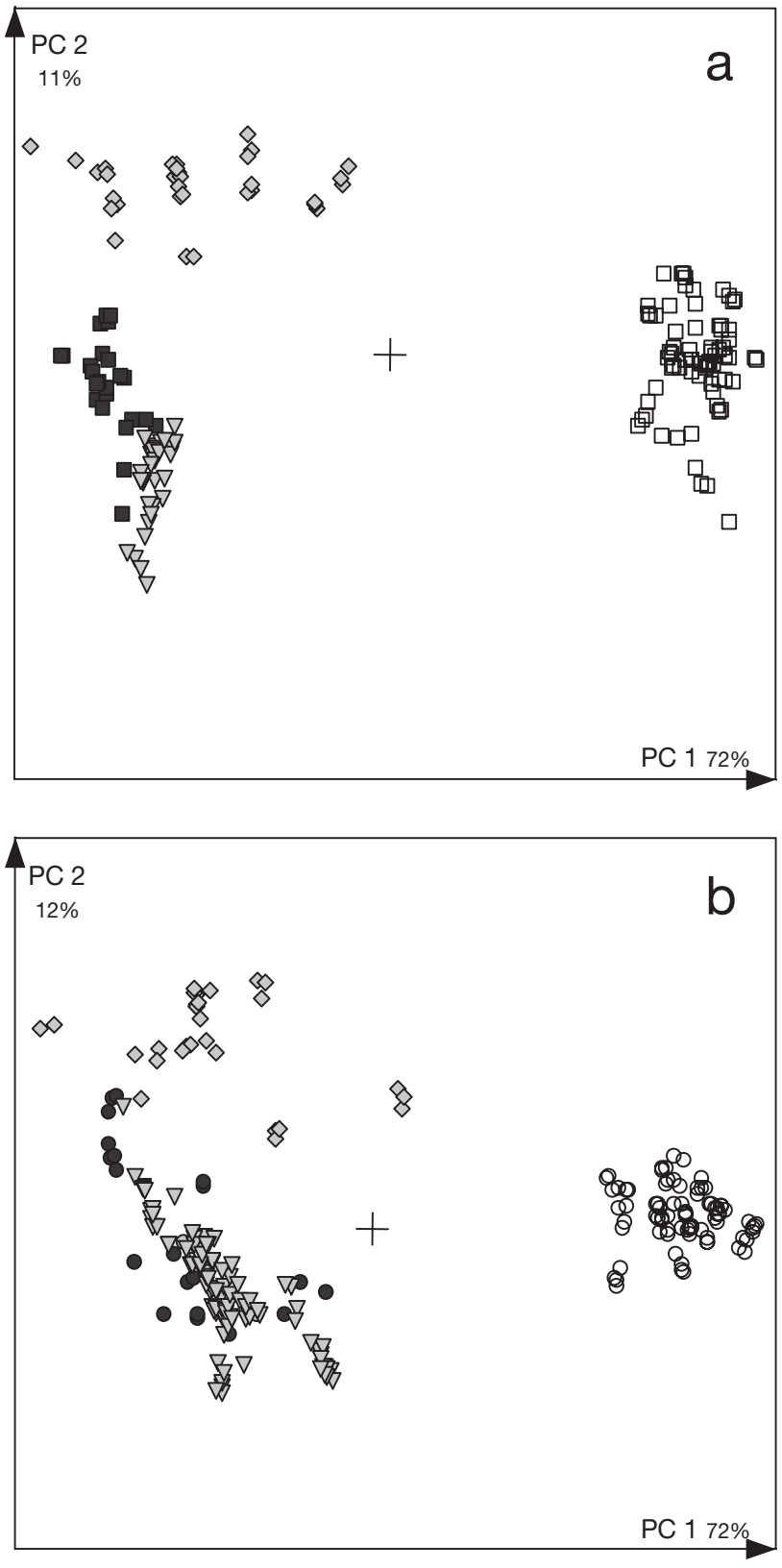

Fig. 4. Phoca spp. and Erignathus barbatus. PC plot of samples from (a) outer and (b) inner blubber of $(\square, O)$ Baikal seals $(N=30),(\square, 0)$ ringed seals $(N=12),(\nabla)$ harp seals $(N=10)$ and $(\diamond)$ bearded seals $(\mathrm{N}=9)$ based on $22 \mathrm{FA}$, with several replicate samples for each seal

layer should obviously be used in comparisons with the FA composition of the prey, since the deposition of ingested lipids takes place in the inner layer. The inner blubber of both seal species has an FA composition that differs from that of their prey (Table 2, Figs. 2 \& 3). However, even though there is a large difference between freshwater and marine fishes, the change in relative abundance from prey to inner blubber is 


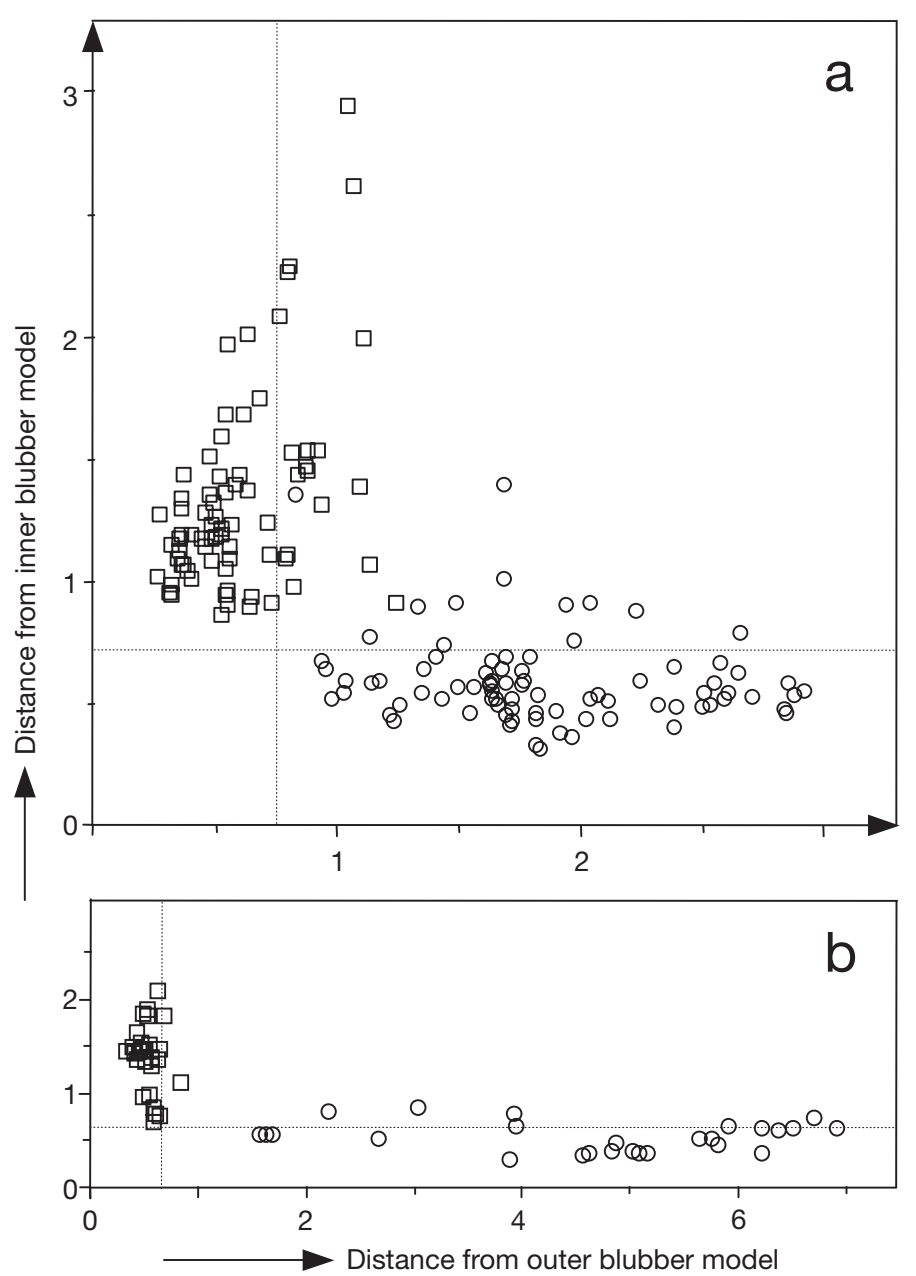

Fig. 5. (a) Phoca sibirica; (b) P. hispida. Class-distance plots of samples from outer blubber $(\square)$ of adults versus samples of inner blubber (O) from same seals based on all 50 FA, with several replicate samples for each seal. Vertical line: outer limit for outer blubber model, 0.64 in (a), 0,66 in (b); horizontal line: outer limit for inner blubber model, 0.62 in (a), 0.65 in (b)

similar for the 2 seal species, i.e. the change in relative levels is in the same direction for both species for all but 5 of the 50 FA.

\section{FA composition of adults, pups and fetuses}

No correlation between the age of the adult Baikal seals and their FA composition was found. There is a slight difference in FA composition between the genders, but the variation within each sex group precludes significant distinction. However, the 9 pups studied have a FA composition in the blubber that differs from the FA composition of the adults (Fig. 7). In this PC plot the pup-adult difference is manifested along the first $\mathrm{PC}$, and the inner-outer difference along the second
PC. The distinction between the inner and outer layers is complete, while there is some overlap between the samples of pups and adults. However, when the pupadult difference was tested quantitatively and separately for the inner and outer layers by using spacefilling models of the samples within each group and measuring the distance of the samples from both their own and to the other model by SIMCA, a clear distinction between pups and adults was apparent (Fig. 8). The pups had relatively more 18:1n9 and 18:1n7 and less of all n6 and n3 PUFA (Table 2, Fig. 2). The adipose tissue of the fetuses of the Baikal seal had a FA composition distinct from that of the adults and pups. The fetus blubber contained larger amounts of the SFA 16:1n9 and 20:1n11 and less of the other FA, particularly the n3 PUFA (Table 2, Fig. 2).

\section{Temporal difference in FA composition}

Separate, space-filling models were generated for the samples of inner and outer blubber of adult Baikal seals for each of the 2 sampling times, i.e. July 2001 and October 2002. No significant difference between the 2 sampling times was observed for the outer blubber (Fig. 9a), since some of the samples from October 2002 fell inside the model for the samples from July 2001. However, in the case of the inner blubber, the distinction between the seals from the 2 periods was significant (Fig. 9b).

\section{DISCUSSION}

\section{Freshwater versus marine seals}

Diet is the dominant source of FA in the blubber of marine mammals. All FA in the diet are present in the blubber, although in different relative amounts. In addition, the animals themselves synthesize SFA with 14, 16 and 18 carbons, with the MUFA 16:1n7 and 18 :1n9 being quantitatively the most important (Miyazaki \& Ntambi 2003). The composition of the FA in the blubber is the result of complicated processes of deposition, mobilization, biosynthesis, and transport of lipids. Baikal and ringed seals, which are closely related, showed remarkably similar relative levels of the endogenous FA in both the inner and outer blubber, irrespective of large differences in relative levels of these FA in their potential prey species. This may be explained by inherited preferences for a certain FA composition in the blubber triacylglycerols caused by evolutionary adaptation to environment and physicochemical conditions (Käkelä \& Hyvärinen 1996). In the case of those FA that can be endogenously produced, 


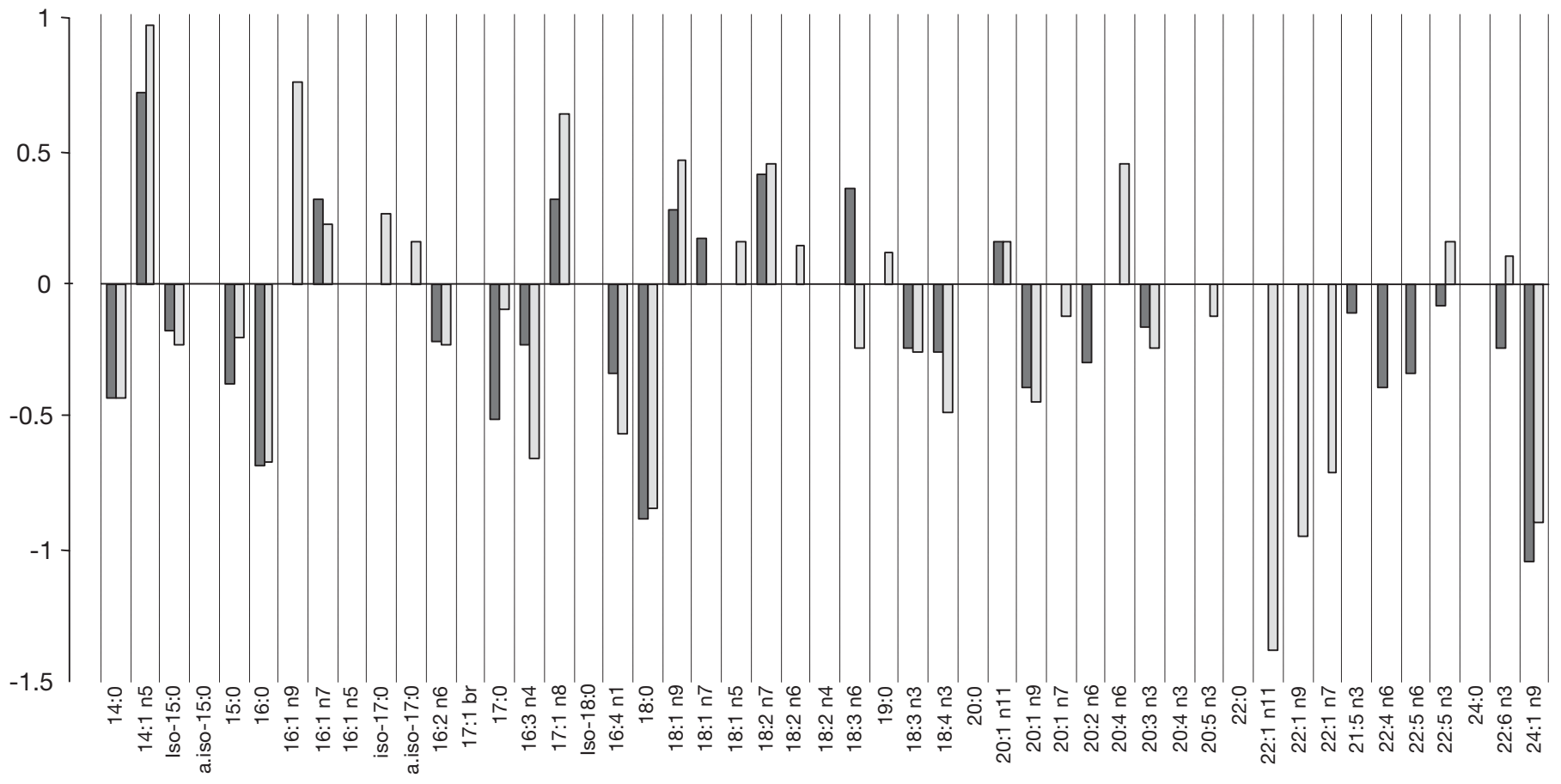

Fig. 6. Phoca sibirica (black bars) and P. hispida (grey bars). Stratification index for blubber FA of adults obtained by subtracting percentage in inner layer from percentage in outer layer and dividing difference by mean of totals for outer and inner layers. FA present at $<0.1 \%$ and FA with stratification index $<0.1$ not included

the differing dietary supplies are then adjusted by synthesis and selective incorporation to fit the inherited requirements (Brockerhoff \& Ackman 1967).

Consequently, the large overall difference in the FA composition of freshwater and marine seals' blubber

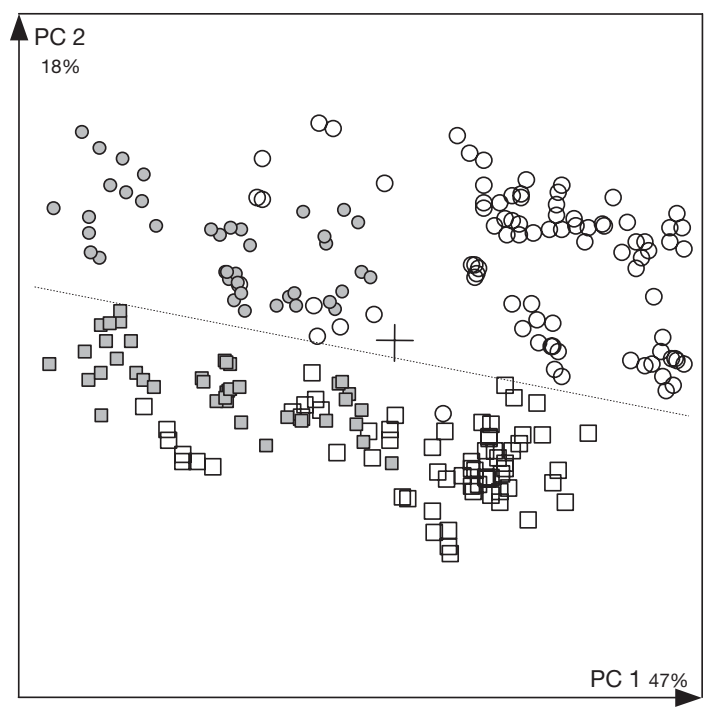

Fig. 7. Phoca sibirica. PC plot of blubber samples from 30 adults and 9 pups based on $40 \mathrm{FA} .(\mathrm{O}, \mathrm{\square})$ inner and outer blubber of adults, respectively; $(O, \square)$ inner and outer blubber of pups, respectively. Several replicate samples used for each seal. Line distinguishes between inner and outer blubber samples
(Fig. 3) is caused by differences in the proportions of long-chain MUFA and PUFA. These FA cannot be endogenously synthesized (Holman 1986), and are therefore derived exclusively from the diet as such, or as their precursors. Thus the proportions of these FA in the blubber cannot be adjusted towards a certain preferred composition by metabolic pathways as easily as those of the SFA and $\Delta 9$-desaturated MUFA mentioned above.

Quantitatively, the largest difference between the Baikal seal and ringed seal blubber was that C20 and C22 MUFA were present in very low relative levels in the Baikal seal blubber. In marine ecosystems, these FA originate from wax esters of crustaceans (Saito \& Kotani 2000). In Lake Baikal fauna, wax esters are absent (Morris 1983). In addition, as a result of differences in the Lake Baikal and Artic Ocean food webs, the Baikal seal blubber is rich in C18- and n6 PUFA, originating at the plankton level (Käkelä et al. 1993, Käkelä \& Hyvärinen 1998), a feature shared by the blubber of the freshwater ringed seal from Lakes Saimaa and Ladoga. The overall increase of n6 PUFA in freshwater seals has occurred at the expense of n3 PUFA, mainly 20:5n3 (Käkelä \& Hyvärinen 1998). High levels of $n 6$ and C18 PUFA and low levels of C20 and C22 MUFA were also observed in a freshwater subspecies of the harbor seal Phoca vitulina mellonae from northern Quebec, Canada, in contrast to its marine 

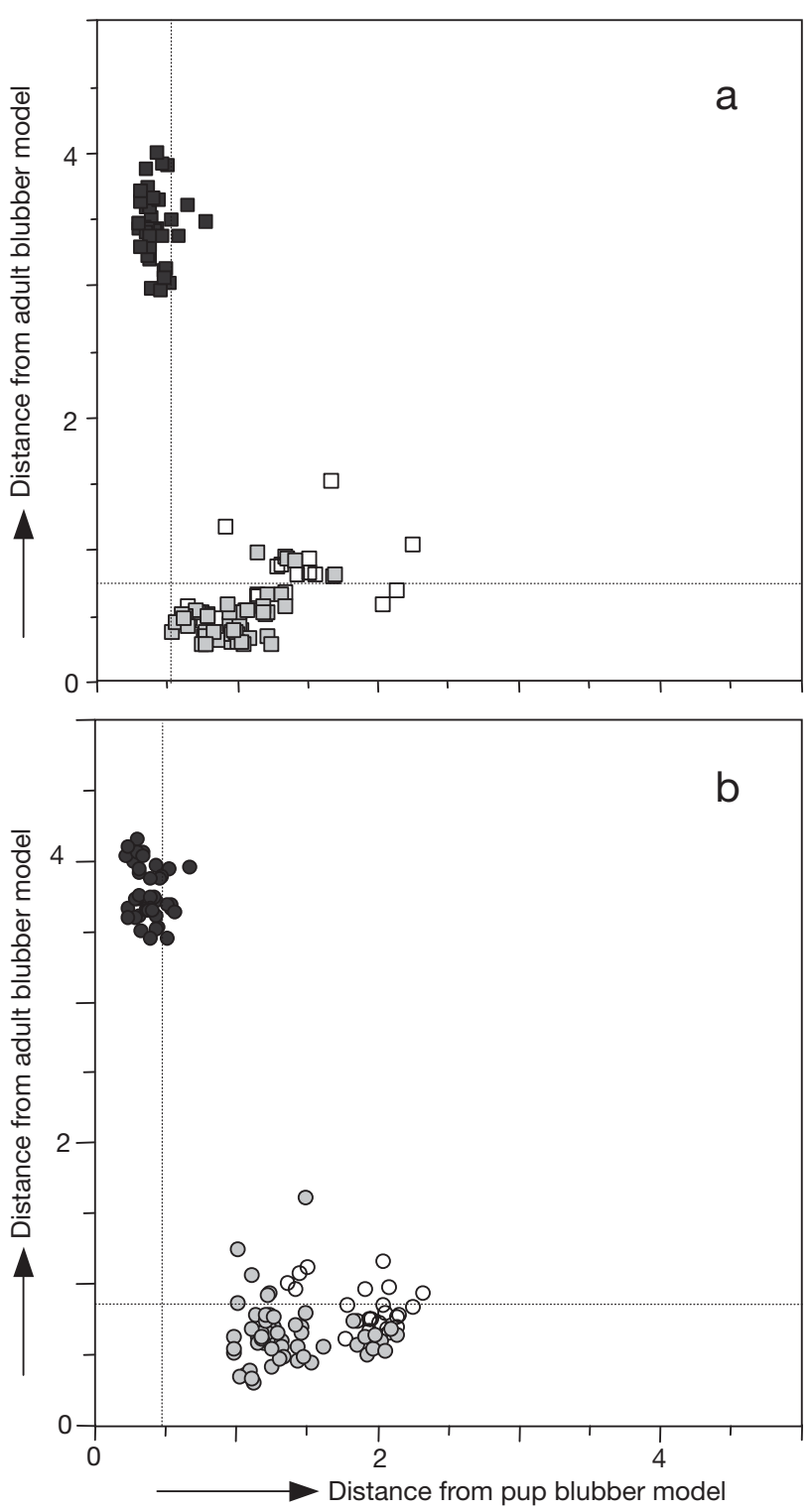

Fig. 8. Phoca sibirica. Class-distance plots of samples of (a) outer and (b) inner blubber from 9 pups $(\mathbf{\square}, \boldsymbol{\bullet})$ versus samples of outer blubber from 30 adults from July $2001(\square, O)$ and October $2002(\square, 0)$ based on 40 FA, with several replicate samples for each seal. Vertical line: outer limit for pups model, 0.52 in (a), 0.46 in (b); horizontal line: outer limit for adult model, 0.75 in (a), 0.85 in (b)

counterparts $P$. vitulina concolor and $P$. vitulina richardsi (Smith et al. 1996). Although no direct comparison of prey FA was made, this was ascribed to the general FA composition of organisms in freshwater evironments (Henderson \& Tocher 1987). In the Lake Baikal fauna, the general composition of FA appears to be closer to that of marine fauna than to that normally associated with freshwater animals (Morris 1984). According to Ju et al. (1997), 3 species of Baikal fishes

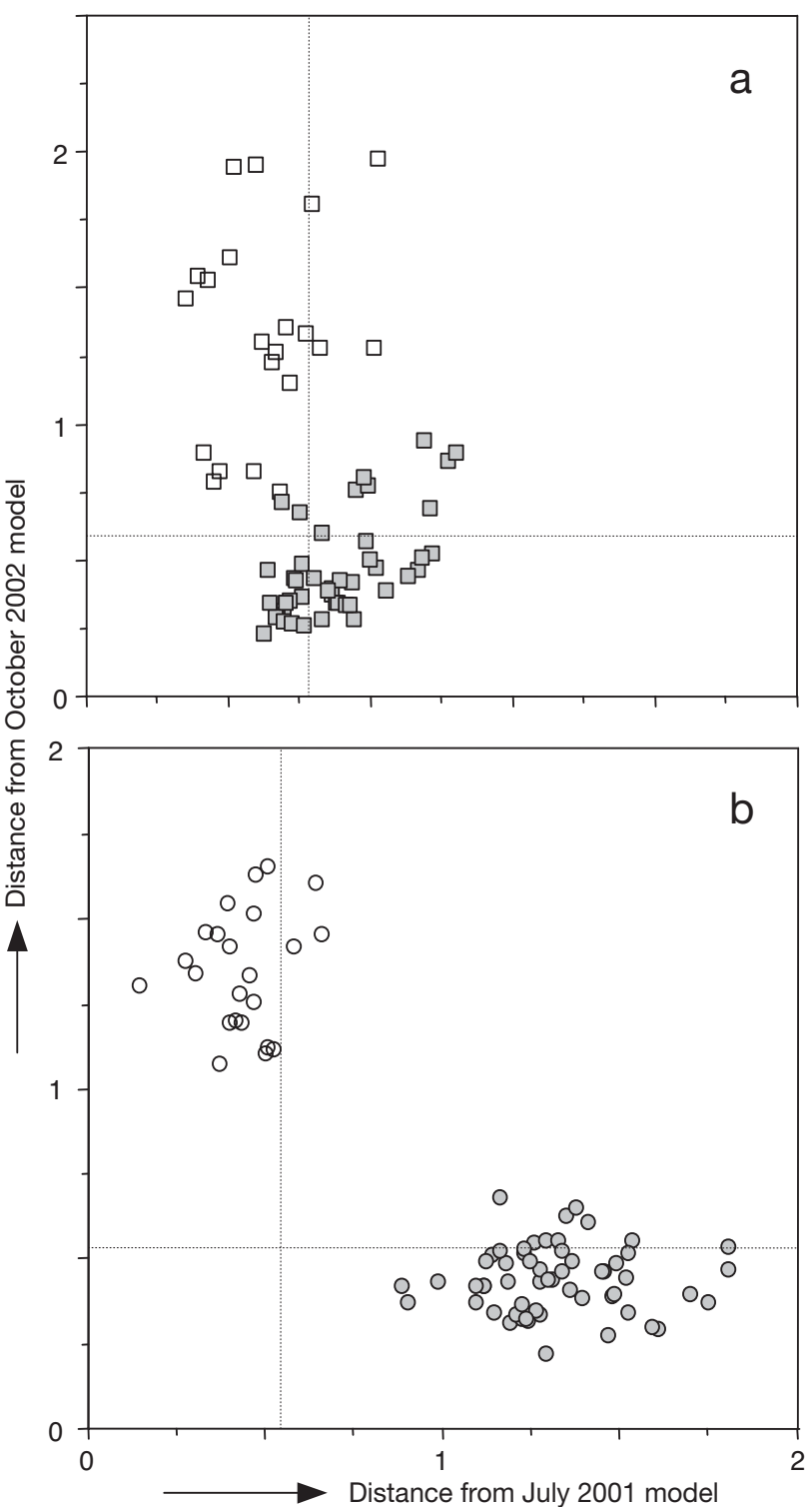

Fig. 9. Phoca sibirica. Class distance plots of samples from (a) outer and (b) inner blubber from 5 adults from July $2001(\square, O)$ versus samples of outer blubber from 25 adults from October $2002(\square, 0)$ based on 40 FA, with several replicate samples for each seal. Vertical line: outer limit for July 2001 model, 0.79 in (a), 0.54 in (b); horizontal line: outer limit for the October 2002 model, 0.59 in (a), 0.53 in (b)

have a fatty acid composition more typical of marine species (with a predominance of $\mathrm{n} 3 \mathrm{FA}$ ) than of many freshwater species.

The odd-chain SFA and MUFA were more abundant in the blubber of the Baikal seal than in the ringed seal blubber. In oceanic waters, these FA are more plentiful in demersal than in pelagic fishes (Käkelä et al. 2005), and may represent different contributions of bottom organisms via demersal fishes to the seals in the 2 
systems. However, it has also been suggested that they may originate (at least partly) from micro-organisms in the fish gut (Ju et al. 1997).

\section{FA stratification}

The differences between the FA in the inner and outer blubber layers are the same in the Baikal seal and the ringed seal, albeit with large differences in the relative abundances of the FA in the 2 species (Fig. 6). In fact, the same inner-outer differences occur in all marine mammals, cetaceans and pinnipeds, being generally manifested in higher levels of the MUFA with 14, 16 and 18 carbons in the outer blubber, and lower levels of all the other FA (Fredheim et al. 1995, Koopman et al. 1996, Koopman 2001, Best et al. 2003, Olsen \& Grahl-Nielsen 2003). While the type of stratification appears to be universal, the degree of stratification varies among species (Koopman 2001, Olsen \& Grahl-Nielsen 2003).

Koopman (2001) found that the degree of FA stratification among odontocete species is correlated with their habitat temperature. Insulation would thus seem an important factor in determining the composition of the blubber, although Lockyer et al. (1984) maintained that the general insulative function of blubber is very efficient. The role of the outer layer should therefore be considered more as thermoregulative than as insulative. It has been shown that ambient temperature fluctuations affect blubber temperature very little below a depth of $1.5 \mathrm{~cm}$ (Shepeleva 1973).

Irrespective of blubber function, the explanation for FA stratification is usually based on physicochemical properties of the FA and mechanisms involved in the processes of deposition and mobilization of lipids to and from the blubber. Thus, as far back as 1932, Heyerdahl found that the inner layer of the blubber of cetaceans was more unsaturated than the outer layer. He suggested that unsaturated fat is more easily emulgated and hydrolyzed for transport and deposition, which takes place in the inner blubber layer during fattening. Saturated fat, with a higher melting point, is deposited more slowly. During fasting and lactation it is, for the same reason, the inner, more unsaturated fat that is mobilized, leaving fat with a lower degree of unsaturation in the outer parts for insulation.

Nowadays, the endogeneous FA, i.e. SFA and MUFA with 14, 16 and 18 carbons, are usually involved in attempts to explain the stratification of the blubber of marine mammals. (Hooker et al. 2001, Koopman 2001). The theory is that the endogenously synthesized FA are less readily mobilized and therefore dominate the more stable outer layer, while the other FA, which are of dietary origin, are stored in or mobilized from the inner layer, depending on fattening or fasting conditions. In fact, the dietary FA have been considered as 'diluting' the endogeneous FA in the inner layer (Koopman et al. 1996).

The results of this study do not support the explanation of an exclusively physicochemically determined process for the distribution of the endogeneous and dietary FA between the inner and outer blubber layers, since the endogeneous SFA, with 14, 16 and 18 carbons, are clearly enriched in the inner layer, while their monounsaturated analogs are enriched in the outer layer. In fact, both the relative levels and stratification indexes of the endogeneous SFA and MUFA with 14, 16 and 18 carbons are similar for the Baikal seal and the ringed seal (Table 2, Fig. 6).

It is generally accepted that the melting points of adipose tissue lipids are adjusted by $\Delta 9$-desaturation of SFA to produce MUFA, which in the case of seals is mainly $16: 1 \mathrm{n} 7$. The activity of this desaturase adapts rapidly to tissue temperature and is also regulated by the PUFA content of the tissue (Ntambi 1999). The desaturation of ingested 16:0 to $16: 1 \mathrm{n} 7$ was recently evidenced in gray seal Halichoerus grypus pups using radiolabelled precursors (Budge et al. 2004). The superficial layers of blubber of the marine mammals in cold and tropical waters are rich in $\Delta 9$-desaturated MUFA, which may mean that this is an inherited feature.

The preferential deposition of C20 and C22 MUFA in the inner bubber can be explained by their high melting points. In addition, experiments with laboratory rats suggest that continuous weight-cycling, that is especially likely to occur in the metabolically very active inner blubber, will increase the proportion of long-chain MUFA and SFA in adipose tissue triacylglycerols through the preferential hydrolysis of C16 and C18 MUFA and PUFA (Raclot et al. 1995).

In those studies in which the FA composition of both the inner and outer blubber has been compared with the composition of the diet, it has been shown that the composition of the inner blubber is closest to the composition of the diet (Olsen \& Grahl-Nielsen 2003; Andersen et al. 2004). This is also the case for the Baikal and ringed seals (Fig. 3).

The dietary effect on the FA composition of the inner layer is, however, not strong enough for a complete transfer of FA composition from diet to blubber. Both endogeneous synthesis of FA (as discussed above) and a selective process during uptake occur. Iverson et al. (2004) established calibration coefficients for each FA for 3 diet-prey systems in an attempt to estimate the composition of the seal diet based on blubber FA.

The difference between the FA of the inner and outer blubber layers is greater in the adult Baikal seals 
than in the pups. This is in accordance with findings for the harbor porpoise Phocoena phocoena (Koopman et al. 1996).

Samples from the middle of the blubber column of the 5 Baikal seals caught in July 2001 had FA compositions intermediary between the inner and outer layers (data not shown). This was also reported for 4 other species of seals by Fredheim et al. (1995), and indicates a continous transition between the inner and outer layers. The blubber column cannot therefore be considered to be composed of only 2 distinct layers. Thus, when investigating recent dietary influence, only the innermost few millimeters of the blubber should be subsampled, while when investigating interspecific differences, only thin slices just below the skin should be used. For investigations of the stratification of the blubber many thin subsamples should be retrieved between the muscles and the skin.

\section{Gender and age differences}

The FA composition differed slightly between sexes in both the inner and outer blubber layers, although this difference was not significant. Samuel \& Worthy (2004) observed a significant difference between male and female bottlenose dolphins Tursiops truncatus for 2 FA in the inner blubber layer. It would be worthwhile to determine if such differences are caused by dietary or physiological factors.

The FA composition of the adipose tissue of the Baikal seal fetuses and of the blubber of the pups differed from that of the adult blubber in containing less PUFA and more short- and medium-chain SFA and MUFA (Table 2, Fig. 2). This difference was larger in the fetuses than in the pups. A similar difference was found between the blubber of newborn hooded seal Cystophora cristata pups and adult blubber (Iverson et al. 1995) and between the blubber of newborn white whale Delphinapterus leucas calves and that of their mothers (Birkeland et al. 2005). Seals, e.g. hooded and harbor Phoca vitulina seals, appear to be able to transfer PUFA directly to the fetus (Iverson et al. 1995). These are probably used largely to build-up the inner organs and tissues of the growing fetus, and thus the amount of PUFA stored in the adipose tissue is relatively small. The inner organs of the Baikal seal fetus are rich in PUFA, with relative amounts close to those in the adult organs (Käkelä et al. unpubl. results). Endogenous production of SFA and MUFA (which may occur at an early age in order to ensure rapid deposition of blubber and thus ensure sufficient insulation and avoid loss of metabolic energy for heat production) may also contribute to the differences between fetuses, pups and adults. The very high relative amounts of
SFA in fetus blubber can apparently be tolerated because of the stable, high temperature of the fetus.

After parturition, the blubber of the pups gradually attains the FA composition of adult blubber. This change from newborn to adult composition apparently corresponds with the lactation period. Thus, for hooded seal pups, the change takes place over the very short lactation period of $4 \mathrm{~d}$ (Iverson et al. 1995), while white whale calves (whose lactation period lasts $>1 \mathrm{yr}$ ) attain a blubber FA composition that is close to that of their mothers after 1 yr (Birkeland et al. 2005). In hooded seals, adult blubber and milk have almost the same FA composition, and the change in the composition of pup blubber to that of adult blubber led Iverson et al. (1995) to conclude that the ingested FA were deposited directly and without modification into pup blubber. This was not the case for the white whales, where adult blubber and milk had significantly different FA compositions, but nevertheless the blubber of the growing calves attained the same FA composition as that of the adults despite the different composition of their diet (Birkeland et al. 2005).

The duration of lactation for the Baikal seal is between 45 and $75 \mathrm{~d}$, depending on the break-up of the ice. Thus, lactation is completed earlier in the southern than in the northern parts of the lake (Egorova \& Petrov 1998). If the Baikal seal pups follow the same pattern as the hooded seal and white whale, then it is reasonable that the 20 to $30 \mathrm{~d}$ old pups in this study have a blubber FA composition which is still different from the adults.

The FA composition of the fetus blubber had 2 peculiar features: (1) 16:1n 9 (the double-bond position of which suggests that it has been chain-shortened in peroxisomes) is clearly higher than in pups and adults. Thus, fetuses may use peroxisomal chain-shortening to adjust lipid fluidity. A relative enrichment of 16:1n-9 was also observed in the poikilothermic outer blubber of ringed seals by Käkelä \& Hyvärinen (1996). (2) the fetus blubber contains a high percentage of 20:1n11. In the Baikal seal this cannot be explained by chainshortening of $22: 1 \mathrm{n} 11$, since this FA only occurs in trace levels in blubber and prey. Thus, 20:1n11 may arise from repeated chain-elongation followed by normal $\Delta 9$-desaturation of 20:0. This is theoretically sound, since chain-elongation should be more active in the warm blubber of the fetus than in the cold blubber of an adult seal.

The difference in the FA composition of blubber of the adult Baikal seals captured in July 2001 and October 2002, revealed by SIMCA (Fig. 9), could have been due to physiological or dietary factors. The different seasons of capture, i.e. mid-summer and late fall (with commencement of ice cover in the bays in the latter season), may induce compositional changes to meet 
the different insulation requirements and also to maintain the fluidity of the blubber and its membranes. These requirements would most likely affect the outer blubber layer, but we observed significant differences only in the inner layer. It is therefore reasonable to conclude that temperature is not the main determinant of the differences between the 2 sampling periods, but that differences in prey play a more important role.

The Baikal seals have been reported to migrate freely over large distances in the lake (Petrov 1997), and may indeed cover considerable distances in a short time (Watanabe et al. 2004). The seals from the 2 locations in the present study cannot therefore be considered as belonging to 2 separate colonies foraging on different prey, as was the case for the grey seals in Scottish waters studied by Walton \& Pomeroy (2003). The differences in diet that caused the differences in the FA composition of the inner blubber must therefore be due to a change in the available prey. It is also possible that the seals consumed the same prey species, and that the FA composition of the prey changed between the 2 sampling periods.

This comparative study has shown that both endogenous factors and the general lipid composition of the ecosystem have influence on the layering and composition of FA in the blubber of the top predators, Phoca sibirica and $P$. hispida. The similar, systematic vertical differences in the blubber column of freshwater and marine seals require further research to determine how the various factors affect the blubber FA composition in the different vertical layers and to reveal the connection between blubber composition and its many functions.

Acknowledgement. We thank Christian Lydersen, Norwegian Polar Institute, for supplying the samples of blubber from ringed seals and polar cod.

\section{LITERATURE CITED}

Andersen SM, Lydersen C, Grahl-Nielsen O, Kovacs KM (2004) Diet of harbour seals (Phoca vitulina) at Prins Karls Forland, Svalbard. Can J Zool 82:1230-1245

Bang HO, Dyerberg J (1976) Composition of food consumed by Greenland eskimos. Acta Med Scand 200:69-73

Best NJ, Bradshaw CJA, Hindell MA, Nichols PD (2003) Vertical stratification of fatty acids in the blubber of southern elephant seals (Mirounga leonina): implications for diet analysis. Comp Biochem Physiol B 134:253-263

Birkeland A, Kovacs KM, Lydersen C, Grahl-Nielsen O (2005) Transfer of fatty acids from mothers to their calves during lactation in white whales Delphinapterus leucas. Mar Ecol Prog Ser 298:287-294

Brockerhoff H, Ackman RG (1967) Positional distribution of isomers of monoenoic fatty acids in animal glycerolipids. J Lipid Res 8:661-666

Budge SM, Cooper MH, Iverson SJ (2004) Demonstration of the deposition and modification of dietary fatty acids in pinniped blubber using radiolabelled precursors. Physiol Biochem Zool 77:682-687

Demchenko AI, Zavarzina GA, Lavrentyeva VV, Usov AA (1982) Actual problems of pharmaceutics (aktualnye problemy farmacii). Nauka, Novosibirsk

Durnford E, Shahidi F (2002) Comparison of FA compositions of selected tissues of phocid seals of eastern Canada using one-way and multivariate techniques. J Am Oil Chem Soc 79:1095-1102

Egorova LI, Petrov EA (1998) Some ecological-physiological aspects of diet and growth of Baikal nerpa pups (Pusa sibirica). J Evol Biochem Physiol 34:591-597

Fredheim B, Holen S, Ugland KI, Grahl-Nielsen O (1995) Fatty acid composition in blubber, heart and brain from phocid seals. In: Blix AS, Walløe L, Ulltang Ø (eds) Whales, seals, fish and man. Elsevier, Amsterdam, p 153-168

Grahl-Nielsen O, Barnung T (1985) Variation in the fatty acid profiles of marine animals caused by environmental and developmental changes. Mar Environ Res 17:218-222

Grahl-Nielsen O, Andersen M, Derocher AE, Lydersen C, Wiig Ø, Kovacs KM (2003) Fatty acid composition of the adipose tissue of polar bears and of their prey: ringed seals, bearded seals and harp seals. Mar Ecol Prog Ser 265:275-282

Grahl-Nielsen O, Andersen M, Derocher AE, Lydersen C, Wiig Ø, Kovacs KM (2004) Reply to comment on GrahlNielsen et al. (2003): sampling, data treatment and predictions in investigations on fatty acids in marine mammals. Mar Ecol Prog Ser 281:303-306

Henderson RJ, Tocher DR (1987) The lipid composition and biochemistry of freshwater fish. Prog Lipid Res 26: 281-347

Heyerdahl EF (1932) Hvalindustrien. En teknisk-kjemisk undersøkelse. I Råmaterialet. Publ 7. Kommandør Chr. Christensens Hvalfangstmuseum, Sandefjord

Holman RT (1986) Control of polyunsaturated acids in tissue lipids. J Am Coll Nutr 5:183-211

Hooker SK, Iverson SJ, Ostrom P, Smith SC (2001) Diet of northern bottlenose whales inferred from fatty-acid and stable-isotope analyses of biopsy samples. Can J Zool 19: $1442-1454$

Iverson SJ (2002) Blubber. In: Perrin WF, Würsig B, Thewissen JGM (eds) Encyclopedia of marine mammals. Academic Press, San Diego, p 107-112

Iverson SJ, Oftedal OT, Bowen WD, Boness DJ, Sampugna J (1995) Prenatal and postnatal transfer of fatty acids from mother to pup in the hooded seal. J Comp Physiol B 165: $1-12$

Iverson SJ, Field C, Bowen WD, Blanchard W (2004) Quantitative fatty acid signature analysis: a new method of estimating predator diets. Ecol Monogr 74:211-235

Ju SJ, Kucklick JR, Kuzlova T, Harvey HR (1997) Lipid accumulation and FA composition during maturation of three pelagic fish species in Lake Baikal. J Great Lakes Res 23: 241-253

Käkelä R, Hyvärinen H (1996) Site-specific fatty acid composition in adipose tissue of several northern aquatic and terrestrial mammals. Comp Biochem Physiol B 115: 501-514

Käkelä R, Hyvärinen H (1998) Composition of polyunsaturated fatty acids in the liver of freshwater and marine ringed seals (Phoca hispida ssp.) differs largely due to the diet of the seals. Comp Biochem Physiol B 120:231-237

Käkelä R, Hyvärinen H, Vainiotalo P (1993) Fatty acid composition in liver and blubber of the Saimaa ringed seal (Phoca hispida saimensis) compared with that of the ringed seal (Phoca hispida botnica) and grey seal (Halichoerus grypus) 
from the Baltic. Comp Biochem Physiol B 105:553-565

Käkelä R, Käkelä A, Kahle S, Becker PH, Kelly A, Furness RW (2005) Fatty acid signatures in plasma of captive herring gulls as indicators of demersal or pelagic fish diet. Mar Ecol Prog Ser 293:191-200

Koopman HN (2001) The structure and function of the blubber of odontocetes. PhD thesis, Duke University, Durham, $\mathrm{NC}$

Koopman HN, Iverson SJ, Gaskin DE (1996) Stratification and age-related differences in blubber fatty acids of the male harbour porpoise (Phocoena phocoena). J Comp Physiol B 165:628-639

Kvalheim OM, Karstang TV (1987) A general-purpose program for multivariate data analysis. Chemom Intell Lab Syst 2:235-237

Lockyer $\mathrm{CH}$, McConnell LC, Waters TD (1984) The biochemical composition of fin whale blubber. Can J Zool 62: $2553-2562$

Miyazaki M, Ntambi JM (2003) Role of stearoyl-coenzyme A desaturase in lipid metabolism. Prostaglandins Leukot Essent Fatty Acids 68:113-121

Morris RJ (1983) Absence of wax esters in pelagic Lake Baikal fauna. Lipids 18:149-150

Morris RJ (1984) The endemic faunae of Lake Baikal: their general biochemistry and detailed lipid composition. Proc R Soc Biol Sci Ser B 222:51-78

Ntambi JM (1999) Regulation of stearoyl-CoA desaturase by polyunsaturated fatty acids and cholesterol. J Lipid Res 40: $1549-1558$

Olsen E, Grahl-Nielsen O (2003) Blubber fatty acids of minke whales: stratification, population identification and relation to diet. Mar Biol 142:13-24

Pastukhov VD (1993) Nerpa Baikala. Nauka, Novosibirsk

Petrov EA (1997) Allocation of Baikal nerpa, Pusa sibirica. Zool J Linn Soc 76:1202-1209

Petrov EA (2000) Sex-age structure, reproduction and number of the Baikal seals. In: Proc Conf Marine Mammals of the Holarctic. Marine Mammal Council, Arkhangelsk, p 314-317

Raclot T, Mioskowski E, Bach AC, Groscolas R (1995) Selectivity of fatty acid mobilization: a general metabolic

Editorial responsibility: Howard I. Browman (Associate Editor-in-Chief), Storebø, Norway feature of adipose tissue. Am J Physiol 269:R1060-1067

Saito H, Kotani Y (2000) Lipids of four boreal calanoid copepods: origin of monoene fats of marine animals at higher trophic levels in the grazing food chain in the subarctic ocean ecosystem. Mar Chem 71:69-82

Samuel AM, Worthy AJ (2004) Variability in fatty acid composition of bottelnose dolphin (Tursiops truncatus) blubber as a function of body site, season, and reproductive state. Can J Zool 82:1933-1942

Sasaki H, Numachi KI, Grachec M (2003) The origin and genetic relationship of the Baikal Seal, Phoca sibirica, by restriction analysis of mitochondrial DNA. Zool Sci 20: $1417-1422$

Shahidi F, Wanasundara PKJPD, Wanasundara UN (1996) Seal blubber oil: a novel source of $\omega 3$ fatty acids. J Food Lipids 3:293-306

Shepeleva VK (1973) Adaptation of seals to life in the arctic. In: Chapskii KK, Sokolov VE (eds) Morphology and ecology of marine mammals: seals, dolphins, porpoises. John Wiley \& Sons, New York, p 1-58

Smith RJ, Hobson KA, Koopman HN, Lavigne DM (1996) Distinguishing between populations of fresh- and salt-water harbour seals (Phoca vitulina) using stable-isotope rations and fatty acid profiles. Can J Fish Aquat Sci 53:272-279

Stewart B, Petrov EA, Baranov E, Timonin A, Ivanov M (1997) Seasonal movements and dive patterns of juvenile Baikal seals, Phoca sibirica. Mar Mamm Sci 12:528-542

Thiemann GW, Budge SM, Bowen WD, Iverson SJ (2004) Comment on Grahl-Nielsen et al. (2003) 'Fatty acid composition of the adipose tissue of polar bears and of their prey: ringed seals, bearded seals and harp seals'. Mar Ecol Prog Ser 281:297-301

Walton M, Pomeroy P (2003) Use of blubber fatty acid profiles to detect inter-annual variations in the diet of grey seals Halichoerus grypus. Mar Ecol Prog Ser 248:257-266

Watanabe Y, Baranov EA, Sato K, Naito Y, Miyazaki N (2004) Foraging tactics of Baikal seals differ between day and night. Mar Ecol Prog Ser 279:283-289

Wold S, Albano C, Dunn III WJ, Edlund U and 6 others (1984) Multivariate data analysis in chemistry. NATO ASI Ser C Math Phys Sci 138:17-97

Submitted: May 31, 2005; Accepted: September 1, 2005

Proofs received from author(s): December 6, 2005 